\title{
CONGENITAL ANOMALIES IN CHILDREN OF UKRAINE: 25-YEAR MONITORING OF MORBIDITY AND PREVALENCE
}

10.36740/WLek202010116

\author{
Oleksandr P. Volosovets ${ }^{1}$, Tetyana 0. Kryuchko ${ }^{2}$, Viktor L. Veselskyi ${ }^{3}$, Sergii P. Kryvopustov ${ }^{1}$, Tetiana M. Volosovets ${ }^{4}$, \\ Viktor Y. Shatilo5, Veronyka M. Dudnik ${ }^{6}$ \\ 'BOHOMOLETS NATIONAL MEDICAL UNIVERSITY, KYIV, UKRAINE \\ ¿UKRAINIAN MEDICAL STOMATOLOGICAL ACADEMY, POLTAVA, UKRAINE \\ ${ }^{3}$ NATIONAL ACADEMY OF MEDICAL SCIENCES OF UKRAINE, KYIV, UKRAINE \\ ${ }^{4}$ SHYPUK NATIONAL MEDICAL ACADEMY OF POSTGRADUATE EDUCATION, KYIV, UKRAINE \\ 'ZHYTOMYR MEDICAL INSTITUTE, ZHYTOMYR, UKRAINE \\ ${ }^{6}$ VINNYTSIA NATIONAL PIROGOV MEMORIAL MEDICAL UNIVERSITY, VINNYTSIA, UKRAINE
}

\begin{abstract}
The aim: Of the work was to study 25 -year trends in the incidence of congenital anomalies in the child population of Ukraine in order to determine the impact of ecotoxic environmental factors on their development, in particular radiation.

Materials and methods: Methods of statistical assessment, epidemiological analysis of materials at the Center for Medical Statistics of the MOH of Ukraine were used. Results: The rate of congenital anomalies growth for the recent 25 years has exceeded the growth rate of the total incidence in the child population of Ukraine by 1.6 times, occupying the leading place in Europe by the level of environment pollution. Over the last 25 years, the growth of the Ukrainian children's congenital anomalies incidence level by $59.5 \%$ is observed, mostly in children from large industrial regions of Ukraine, due to the significant ecotoxic effect of pollutants on the child's body. Children living permanently in the areas contaminated by the Chernobyl accident had significantly higher rates of congenital anomalies in 1986 than in the early 1990s, but over the recent 25 years the incidence in this contingent has decreased.

Conclusions: The results of such long-term studies performed by a group of leading Ukrainian scientists from different regions of Ukraine indicate that in children experiencing negative effects of ecotoxic factors, including radiation, an increase in the detection and prevalence of congenital defects is observed, which requires complex international and intersectoral measures to prevent and reduce child mortality.
\end{abstract}

KEY WORDS: children, morbidity, congenital anomalies, the Chernobyl disaster, environment

Wiad Lek. 2020;73(10):2193-2197

\section{INTRODUCTION}

A negative impact on the mother's body during pregnancy is due to a number of environmental factors, such as chemicals, pesticides, certain drugs, alcohol, tobacco, psychoactive substances and radiation exposure, which may increase the risk of developing a fetus or newborn infant, among which the most severe are cardiac defects, cerebromedullary tube defects and the Down syndrome, which occupy the second place in the structure of infant mortality causes both in Ukraine and throughout the world.

Analysis of the incidence and prevalence of diseases among the child population of Ukraine, infant mortality rates in recent decades shows that they are significantly higher than the European mean indices (in 2018, the infant mortality rate in Ukraine was 7.0 per 1000 live births versus $3-5 \%$ in the EU countries).

Growth in the birth rate of children with congenital anomalies (development defects), deformities and chromosomal abnormalities (hereinafter referred to as CA) in a particular region is one of the most accurate markers of its environmental disadvantage due to a number of factors. Given this, a number of researchers have estimated the birth rate of children with CA among the population living in radiation-contaminated territories after the Chernobyl accident $[1,2,3]$.

Nowadays, one of the leading places in the development of child diseases in Ukraine is the impact of the ecologically polluted environment, which includes the consequences of the Chernobyl nuclear power plant accident (hereinafter - ChNPP) in 1986. According to the current legislation of Ukraine, CAs are assigned to the List of diseases and pathological conditions, which risk is increased as a result of the impact of ionizing radiation and other harmful factors on the child's body due to the accident at the Chornobyl NPP. However, according to the data of H. Dolk (1999), the Chornobyl disaster did not significantly affect the incidence of congenital anomalies in Europe, which confirms the idea of Lee M. Pachter's (2019) that $40 \%$ to $70 \%$ of pathological 
conditions are caused not only by environmental factors but also by social and economic conditions, behavior and lifestyle of the individual $[4,5]$.

\section{THE AIM}

The aim of the work was to determine trends in the incidence of congenital anomalies of the pediatric population from the regions with territories of radiological control (hereinafter referred to as the TRC) after the Chornobyl accident compared to other regions of Ukraine in dynamics over the last 25 years.

\section{MATERIALS AND METHODS}

The 25-year studies of trends in the incidence and prevalence of CA in children aged 0-14 years living in the regions with territories of radiological control after the Chernobyl accident and in other regions of Ukraine. A separate group consisted of children who were born from the participants of the Chernobyl disaster elimination and were referred to the victims of the Chornobyl disaster according to the current legislation.

The study was carried out in compliance with the main provisions of the ICH GCP and the Declaration of the World Medical Association "Ethical Principles for Medical Research with Human Involvement as an Object of Study" (Seoul, 2008), the Convention on the Protection of Human Rights and Dignity for the Use of Biology and Medicine, adopted by the countries - members of the Council of Europe (Convention on Human Rights and Biomedicine, 2007) and the current regulations of the NAU of Ukraine on bioethical expertise of medical and biological research and clinical trials of medicinal products and medical technologies in compliance with the Recommendations of Ethics Committees for the Expertise of Biomedical Research.

Statistical assessment methods were used, namely the W - Wilcoxon rank criterion for comparing the incidence of CA in children from the same regions of Ukraine at different time intervals, and the statistical analysis of the Health Statistics Center of the Ministry of Health of Ukraine for the latest 25 years. The cluster assessment of Ukraine's regions according to the levels of infant morbidity with CA was carried out by means of the correlation between the infant morbidity indices with the CA and the presence of ecological disadvantage zones arising, in particular, as a result of the Chornobyl accident.

\section{RESULTS}

According to the Health Statistics Center at the Ministry of Health of Ukraine, the incidence in children aged 0-14 years with congenital anomalies in 2017 amounted to 40703 new cases of CA or 6.22 per 1 thousand children (out of 6093 cases of CA were first detected in children of the first year of life). In the list of ranked places in the incidence of childhood diseases, CA occupied the 14th place out of 17. The share of CA among other diseases in children was $0.42 \%$. For comparison, in 1993, 47007 cases or $4.36 \mathrm{CA}$ cases were first identified. It should be noted that for the whole of 25 years the rate of the child CA morbidity increase exceeded by 1.6 times the growth rate of the overall morbidity in the child population of Ukraine, but unevenly, depending on the region of residence of the children.

The greatest number of CA in 2017 was first detected in the city of Kyiv (16.16 per 1000 children), in the Kirovograd (12.39), Kharkiv (9.95), Vinnitsa (9.03), Zaporizhia (7.89), Rivne (7.63), Dnipropetrovsk (7.51), and Kyiv (6.83) regions. Among these regions, only three - Vinnytsia, Rivne and Kyiv - belong to the areas with territories of radiological control designated in accordance with applicable law.

As a result of CA, 178 children died during the first year of life, including 75 from congenital heart defects, accounting for $31.2 \%$ of all reported causes of infant mortality.

In 1993, among the leaders in the CA incidence in children were the regions with territories of radiological control: Sumy (5.9 per 1000 children), Rivne (5.4), Ivano-Frankivsk (4.8), Vinnytsia (4.5) and Kiev (4,2). From other regions 25 years ago, a significant number of CA was detected in children: Lviv region -4.8 per 1000 children, Zaporizhzhya and Transcarpathian regions, which amounted to 4.6 cases per 1000 children, the Crimea AR (4.5), Ternopil region $(4,3)$.

That is, 25 years ago, there were more regions with territories of radiological control (TRC) among the leaders in terms of morbidity levels: Sumy, Ivano-Frankivsk, Rivne, Vinnytsia and Kyiv regions. In general, in the early 1990s, the incidence rates of congenital anomalies of the pediatric population living in the regions with TRC exceeded the national rates and the incidence rates of children with CA in other regions of the country, "contaminated" as a result of the Chornobyl accident. (fig. 1).

The incidence of congenital anomalies in children of Ukraine in 2017 was 189,242 or 28.96 per 1,000 children. In 1993 , the total of 155,252 cases of CA or 14.2 per 1,000 children were detected. It should be noted that, as a whole, the increase in the CA prevalence in children of Ukraine over 25 years exceeded twice the rate of increase of the disease prevalence rate in the pediatric population of Ukraine as a whole.

The high prevalence of CA in 2017 was recorded in the Kyiv city (45.76 per 1000 children), in the Kharkiv (42.76), Vinnytsia (38.53), Kirovograd (35.19), Chernihiv (34.35), Kherson (34.05), Kyiv (32.38), Chernivtsi (31.73) and Volyn (30.87) regions.

Of the above mentioned areas, four - Vinnytsia, Chernihiv, Kyiv and Volyn - belong to the regions with TRC.

The prevalence of congenital anomalies in children of the first year of life in 2019 was dominated by congenital heart defects (29.2\%), congenital thigh and foot deformities (12.9\%), congenital urinary system defects (10.4\%), other congenital defects development and deformation of the musculoskeletal system (9.9\%), undescended testicle (5.9\%), congenital development defects of the digestive system (5.4\%), congenital development defects of the nervous system (2.2\%), cleft lip and palate (2.4\%), Down disease $(1.9 \%)$. 


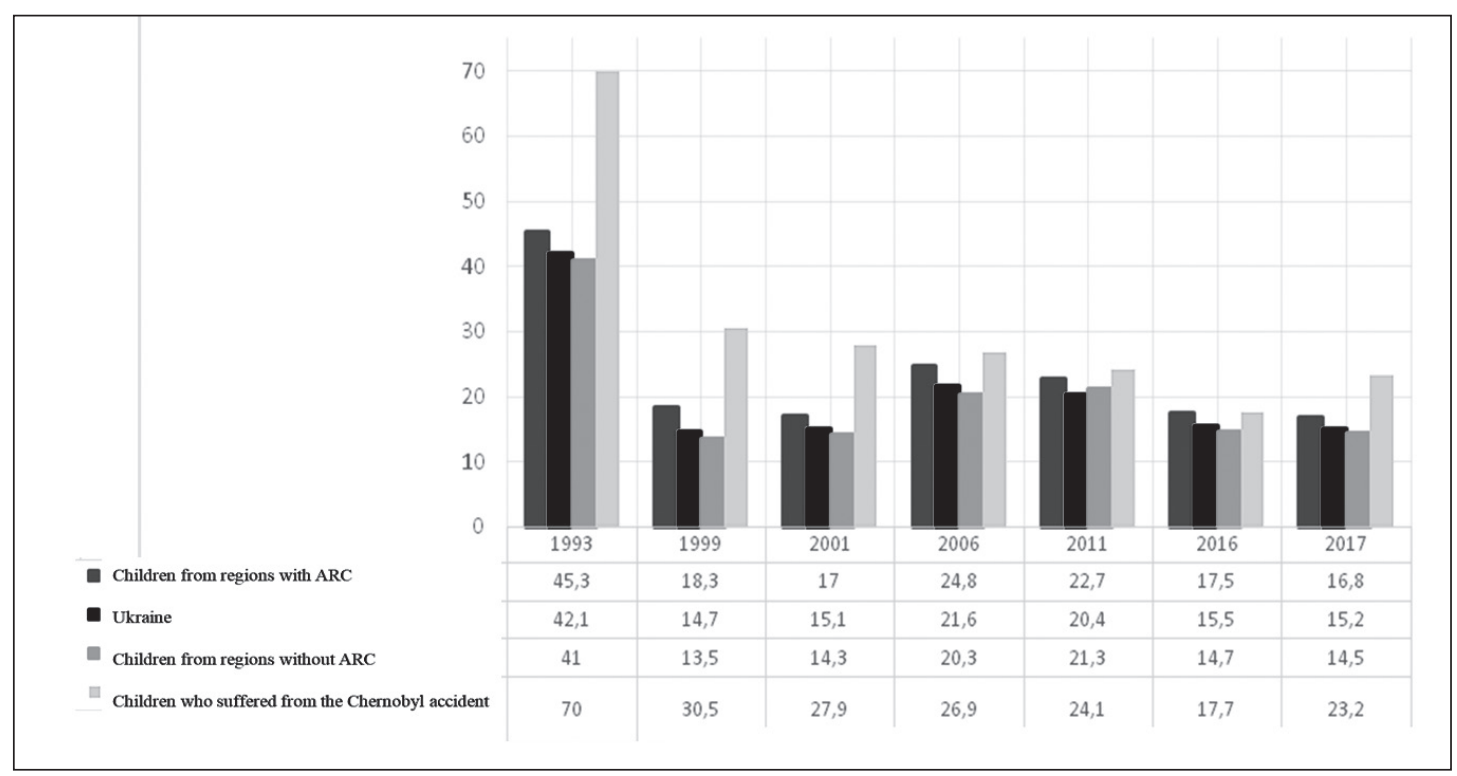

Fig. 1. Comparative dynamics of congenital anomalies incidence rates in children of Ukraine, children affected by the Chornobyl disaster, children from regions with TRC, regions without TRC (1993 - 2017).

Table I. Clustering of Ukrainian regions by morbidity levels of congenital anomalies

\begin{tabular}{|c|c|c|}
\hline $\begin{array}{l}\text { The CA incidence rate } \\
\text { in children }\end{array}$ & $\begin{array}{l}\text { Regions with territories } \\
\text { of radiological control }\end{array}$ & $\begin{array}{l}\text { Regions without territories } \\
\text { of radiological control }\end{array}$ \\
\hline $\begin{array}{l}\text { Regions with a very high CA incidence } \\
\text { in children }\end{array}$ & & $\begin{array}{c}\text { Kyiv city } \\
\text { Kirovohrad region } \\
\text { Kharkiv }\end{array}$ \\
\hline $\begin{array}{l}\text { Regions with high CA incidence } \\
\text { in children }\end{array}$ & $\begin{array}{l}\text { Vinnytsia } \\
\text { Rivne }\end{array}$ & $\begin{array}{l}\text { Zaporizhzhia } \\
\text { Dnipropetrovsk }\end{array}$ \\
\hline $\begin{array}{l}\text { Regions with CA incidence } \\
\text { in children close to the nation-wide index }\end{array}$ & $\begin{array}{l}\quad \text { Kiev } \\
\text { Zhytomyr } \\
\text { Chernihiv }\end{array}$ & $\begin{array}{c}\text { Kherson } \\
\text { Donetsk } \\
\text { Khmelnytsky } \\
\text { Transcarpathian }\end{array}$ \\
\hline $\begin{array}{l}\text { Regions with low CA incidence } \\
\text { in children }\end{array}$ & $\begin{array}{l}\text { Volyn } \\
\text { Ivano-Frankivsk }\end{array}$ & $\begin{array}{c}\text { Одеська } \\
\text { Львівська } \\
\text { Луганська } \\
\text { Миколаївська } \\
\text { Тернопільська } \\
\end{array}$ \\
\hline $\begin{array}{l}\text { Regions with very low CA incidence } \\
\text { in children }\end{array}$ & $\begin{array}{l}\text { Cherkasy } \\
\text { Sumy }\end{array}$ & $\begin{array}{l}\text { Chernivtsi } \\
\text { Poltava }\end{array}$ \\
\hline
\end{tabular}

It should be noted that 25 years ago, among the leaders in the prevalence of $\mathrm{CA}$ in children, were the regions with TRC - Chernihiv (19.0 per 1000 children), Vinnytsia (18.6), Chernivtsi (18.1), Sumy (17.6) prevailed. , Rivne (16.6), Ivano-Frankivsk (15.9) and Zhytomyr (15.5). Among other regions with high CA incidence registered in children were the following: Chernivtsi region with the index amounting to 18.1 per 1000 children, as well as the Poltava (17.9), Transcarpathian (17.5), Kherson (17.3) regions.

In children affected by the Chernobyl accident, 1054 cases of CA or 4.41 per 1000 children were first detected, which is by 1.5 times less than the mean CA incidence of children in Ukraine.

When carrying out a comparative analysis of the CA prevalence in children of Ukraine among the regions with TRC and other regions, it was found that in 6 out of 9 regions with TRC it exceeded the nation-wide figure.

Clustering of Ukraine's regions depending on the incidence rates of congenital anomalies and distribution of regions is presented in table 2. In general, the highest CA incidence rates in children were observed in the Kyiv city, the Kirovograd, Kharkiv, Vinnytsia, Zaporizhia, Kiev, Dnipropetrovsk regions.

The regions with TRC were characterized by high incidence of CA in children of the Vinnytsia, Kyiv, Rivne and Chernihiv regions. The low incidence of CA in children from the Cherkasy and Sumy regions can be explained by the relatively small number of areas with the territories of enhanced radiological control (Table I).

The highest prevalence of CA in children from "contaminated" as a result of the Chernobyl disaster territories 
was observed in the Kharkiv, Zaporizhia, Kiev, Dnipropetrovsk, Mykolaiv regions, which are characterized with a significant ecotoxic load on the child's body due to the most developed industrial and agro-industrial sectors in these regions.

Over the past 25 years, the incidence of congenital anomalies has increased by $59.5 \%(\mathrm{p}<0.05)$, in particular with almost unchanged CA incidence in the regions with territories of radiological control ( $p>0.05)$, but with a tendency to decrease in the early 2000 s. In non-TRC regions, this index has increased significantly by $60.1 \%$ ( $p>0.05$ ). At the same time, the CA incidence in the child population affected by the Chernobyl accident during this period has decreased by $27.9 \%$ (Fig. 1).

It is worth noting that over 25 years of observation in the Vinnytsia, Zhytomyr and Kyiv regions, the highest increase of the CA incidence in children was observed up to $+100 \%,+76,0 \%,+62,62 \%$ respectively, compared to the incidence of CA in 1993. Meanwhile, among other regions with the TRC, the incidence rate growth ranged from + $32.0 \%$ to $+41.0 \%$. A negative growth in the CA incidence was observed in children from the Ivano-Frankivsk and Sumy regions.

Among the regions uncontaminated due to the Chernobyl disaster, the leaders in the the CA incidence growth were the city of Kyiv, the Kharkiv and Kirovograd regions $+389.7 \%,+209.75$ and $+199.6 \%$ respectively. The smallest growth in the CA incidence in children was observed in the Poltava and Chernivtsi regions.

The incidence rates in children with congenital anomalies in the regions with TRC were lower than the nation-wide rates by $18.9 \%(\mathrm{p}>0.05)$ and the incidence rates in children of other regions - by $22.2 \%(\mathrm{p}>0.05)$. The incidence of CA in children affected by the Chernobyl accident was lower by $51.3 \%$ than the nation-wide incidence of this pathology and by $15.7 \%$ than the incidence in children from the regions with TRK (Fig. 1).

The opposite pattern with respect to the CA incidence levels was observed in 1993, when the rates of children affected by the Chernobyl accident were by $44.1 \%$ higher than the nation-wide rates and by $18.5 \%$ higher than the CA incidence in children from radiation contaminated areas, which in their turn, exceeded the incidence rates in children from "conditionally" unpolluted regions by $31.3 \%$.

\section{DISCUSSION}

In 1986, children living permanently in the regions contaminated by the Chernobyl accident in 1986 had significantly higher CA rates than in the early 1990s, but over the latest 25 years the incidence of CA in this contingent has little changed and it is now lower than the similar nation-wide mean index.

The difference between the incidence rates of $\mathrm{CA}$ at the beginning of the 1990s, in favor of the morbidity rates of children affected by the Chornobyl accident and children from the regions with TRC, compared to other regions, indicated the delayed radiation effect on the organism of women in the reproductive age. Only 7 years have passed since the Chornobyl accident. Over 25 years, the effect of the radiation factor as a leader in the occurrence of genetic abnormalities has apparently gradually diminished.

The 25-year observation by a group of leading Ukrainian scientists from different regions found a decrease in the rate of the CA incidence growth in children in the regions with TRC and in children affected by the Chernobyl accident. At the same time, prolonged exposure of the maternal body to the environment contaminated by industry and the agricultural sector has led to a significant increase in the number of children with congenital anomalies in these regions and in the country as a whole.

Comparing the CA incidence in radiation-contaminated regions and regions with significant industrial development, it is necessary to conclude that the non-radiation factors are prevailing over the irradiation by long-life radioisotopes in the possible genesis of congenital anomalies in children.

\section{CONCLUSIONS}

Over the past 25 years, there has been an increase of 59.5\% in the incidence of Ukrainian children with congenital anomalies, with the predominance of this pathology detection in children from large industrial regions of the country with significant ecotoxic pressure of pollutants on the child's body.

At the same time, we note a decrease in the incidence rates of CA in children who are permanent residents in the regions with territories of radiological control, and in children affected by the Chornobyl accident.

\section{REFERENCES}

1. Kvitashvili 0. Shchorichna dopovid pro stan zdorovya naselennya, sanitarno-epidemichnu sytuatsiyu ta rezultaty diyalnosti systemy okhorony zdorovya Ukrayiny za 2014 rik. Kyiv: MOZ Ukrayiny, DU «UISD MOZ Ukrayiny». 2015; 3:135. (in Ukrainian).

2. Bazyka D.A. Trydtsyat rokiv Chornobylskoyi katastrofy: radiolohichni ta medychni naslidky: Natsionalna dopovid Ukrayiny. Kyiv: DU «Natsionalnyy naukovyy tsentr promenevoyi medytsyny Natsionalnoyi akademiyi medychnykh nauk Ukrayiny». 2016;177. (in Ukrainian).

3. Volosovets 0.P., Kryvopustov S.P., Mozyrskaya 0.V. Postchornobylski trendy u poshyrenosti khvorob ta zakhvoryuvanosti dytyachoho naselennya Ukrayiny. Svit Medytsyny ta Biolohiyi.2018; 2 (64):15-24. (in Ukrainian).

4. Dolk H., Nichols R. Evaluation of the impact of Chernobyl on the prevalence of congenital anomalies in 16 regions of Europe. EUROCAT Working Group. Int J Epidemiol. 1999; 28 (5): 941-8. https://doi. org/10.1093/ije/28.5.941

5. Pachter L.M., Kliegman R.M., Geme J.S. Overview of Pediatrics. Nelson Textbook of Pediatrics. Elsevier, 2019; 6.

The work is a fragment of the research project "Diagnosis of cardiovascular, respiratory and digestive disorders in newborns and in children with common noncontagious disease pathology and their therapy", state registration No. 0112 U001772. 
ORCID and contributionship:

Oleksandr P. Volosovets: 0000-0001-7246-0768 ${ }^{\text {A, B, F }}$

Tetyana O. Kryuchko: 0000-0002-5034-4181 ${ }^{\mathrm{C}}$

Viktor L. Veselskyi: 0000-0003-0003-385X ${ }^{A, B, D}$

Sergii P. Kryvopustov: 0000-0001-8561-0710 ${ }^{B}$

Tetiana M. Volosovets: 0000-0001-9950-3748 ${ }^{E}$

Viktor Y. Shatilo: 0000-0001-7362-4787 ${ }^{D}$

Veronyka M. Dudnik: 0000-0001-9711-1329 ${ }^{D}$

\section{Conflict of interest:}

The Authors declare no conflict of interest.

\section{CORRESPONDING AUTHOR}

Tetyana 0. Kryuchko

Ukrainian Medical Stomatological Academy

23 Shevchenko St., 36011 Poltava Ukraine

tel: +38050-3277023

e-mail:drkryuchko@gmail.com

Received: 05.04 .2020

Accepted: 24.08 .2020

A - Work concept and design, B - Data collection and analysis, C - Responsibility for statistical analysis,

D-Writing the article, $\mathbf{E}$-Critical review, $\mathbf{F}$ - Final approval of the article 